\title{
DE LA VERDAD APESTADA \\ Y EL DESTINO TRAICIONADO: SANTA MARÍA DE LAS FLORES NEGRAS
}

\author{
OF THE ROTTEN TRUTH AND DESTINY BETRAYED: \\ SANTA MARIA DE LAS FLORES NEGRAS
}

MARÍA NIEVES ALONSO MARTÍNEZ*

Y LUIS BRAVO CAMPOS $* * *$

\section{RESUMEN}

La novela Santa María de las flores negras aborda, desde distintas perspectivas narrativas, el tema de la matanza de más de tres mil personas (hombres, mujeres, niños) en Iquique en 1909. Rivera Letelier opone la verdad novelesca a lo contado por la historia oficial, integrando múltiples voces a su relato y constituyendo la imagen de un narrador que traiciona su función vigilante e incluso, recurriendo a rasgos del folletín, plantea la utopía de que otro relato, el de justicia, siempre es posible.

Palabras clave: Iquique, panóptico, traición, utopía.

\section{ABSTRACT}

The novel Santa María de las flores negras addresses, from different narrative perspectives, the theme of the mass killing of more than three thousand people (men, women and children) in Iquique in 1909. Rivera Letelier juxtaposes novelistic truth to that of the official history, integrating multiple voices in the narration and constituting an image of a narrator that betrays his function of vigilance, even resorting to features of the romance novel or melodrama to propose that the utopia of another telling, that of justice, is always possible.

Key words: Iquique, panopticon, betrayal, utopia.

Recibido: 22.08.12. Aceptado: 07.10.13.

* Dra. en Filología Hispánica. Profesora del Departamento de Español, Facultad de Humanidades y Arte, Universidad de Concepción. Concepción, Chile. E-mail: malonso@udec.cl

** Candidato a Doctor en Literatura Latinoamericana, Facultad de Humanidades y Arte, Universidad de Concepción. Concepción, Chile. E-mail: luis.bravo.campos@gmail.com 
"Suprimamos la frontera que a los pueblos hace arteros. Enemigos y extranjeros no están fuera, están aquí".

¡Guerra al reino de la guerra! ¡Muerte al reino de la muerte!

(Canción popular, en González Miranda et al., 1998)

\section{LA VERDAD POÉTICA}

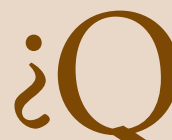

UÉ ANTICIPA, qué prefigura, sobre qué aspecto, llaman la atención los elementos nominales del título de atracción poética de la obra de Rivera Letelier Santa María de las flores ${ }^{1}$ negras 2 ? En sus primeras páginas, la novela anticipa y programa su materia - "Señoras y señores, venimos a contar aquello que la historia no quiere recordar"-, estableciendo así su carácter de contrarrelato, su deber de completar y llenar los vacíos de la historia oficial mediante la verdad novelesca. Parece así querer articular el talante simbólico señalado en su título con el "deber” cronístico de su programación.

De esta forma, podemos pensar en, al menos, dos tipos de discurso que se entrecruzarían y dialogarían en la obra de Rivera Letelier. Hay también variados intertextos que van construyendo un mapa y una cronología rigurosa de los sucesos en su trayectoria y discurrir en el espacio concreto y tiempo histórico; una historia de amor en el espacio de la intensidad ficcional que junto a una alegoría prolongada y circular -el tren, el jote, los jotes, el viaje- expresan un tiempo que expande su existencia. Latencia, más allá del tiempo de lo sucedido en el espacio de la escuela que se proyecta hacia el sur, hacia el lugar imaginado de la utopía, pues lejos de la ciudad apestada y

\footnotetext{
${ }^{1}$ Asociadas analógicamente a las mariposas, al igual que ellas, las flores representan a menudo las almas de los muertos. El color negro se sitúa sobre el eje norte-sur que es el de la trascendencia absoluta y el de los polos según los pueblos coloquen el infierno y el fondo del mundo hacia el norte o hacia el sur, una u otra dirección se considera negra.

${ }^{2}$ El negro está asociado a las tinieblas primordiales, a la indiferencia original. Instalado bajo el mundo, lo negro expresa la pasividad, el estado de muerte consumado... Color del duelo más abrumador que el blanco que también lo es, el negro sería el duelo sin esperanza, la "nada" absoluta... Pero bajo la realidad aparente, el mundo octónico, es también el vientre de la tierra donde se opera la regeneración del mundo diurno (Chevalier: 1991: 747). Color de lo imposible; en boleros, tangos, dichos, asociaciones y rimas populares, el negro está asociado a la desventura y lo infausto.

No obstante las vírgenes medievales y las grandes diosas de la fertilidad son muy comúnmente, negras y, por cierto, mediadoras; las rosas negras son tan raras como las perlas del color que absorbe la luz y no la devuelve evocando el caos y la nada del boquete del alma y del espacio. (Ver Chevalier 1991: 747).
} 
la escuela traicionada, se plantea y se posibilita la huida, el viaje hacia la ciudad imaginada. Observamos entonces una narración que podemos llamar cronística: así ocurrió y así fueron los hechos, y una narración poética que permite acceder a otros niveles de la realidad y contemplar las lentitudes, los miedos y los sueños. Uno es el relato de los "héroes": el otro es el de los "seres humanos". En el entre ${ }^{3}$, Olegario Santana, narrador y personaje. Uno de estos discursos, ya lo anticipamos, entrega la secuencia de los hechos que todos conocemos ya sea por la historia que consagra al general Silva Renard, la Cantata Santa María de Iquique (la épica), el romancero y la poesía popular ${ }^{4}$. En la primera, la crónica, nos encontramos con un narrador omnisciente, intensivo, que domina el relato, y representa el poder sobre la escritura, el sentido, el significado y la verdad de la historia. En este relato se confía en el panóptico literario como ojo que todo lo ve y controla. En la(s) otra(s) abundan símbolos, deseos, traspasos de reinos, ironía y voces menores recuperadas de las versiones de las víctimas populares y del silencio de los relatos oficiales, e incluso en los épicos exaltadores del pueblo. Las narraciones, la del relato "mayor" y las del relato "menor", construyen diferentes estrategias para acercarse a los hechos. Uno elabora su "máquina molar" y el otro, en constante devenir, el arma múltiple y heterogénea de las voces actualizadas en los textos, los recuerdos y el mito. Entre ellas se configura un narrador que ingresa, paulatinamente, al texto y los relatos para traicionar su rol controlador que anticipa el desastre y la tragedia para abrir(se) el relato (él) hacia otra historia que no concluye en la muerte o el regreso fatídico, sino en la posibilidad del viaje. Podría plantearse, siguiendo los esquemas de la macro y microfísica del poder, que las distintas perspectivas buscan imponerse en la novela, que una queda supeditada a la otra, que el relato que va de la vida a la muerte triunfa sobre aquel que iría de la muerte a la posibilidad de vida y que todo se resuelve en muerte y fracaso o en denuncia y alegato político. O viceversa. Pero, a medida que la historia va desarrollándose, en sus intersticios aparece lo otro, la diferencia, sin que nos sea posible encontrar el nexo entre ambos extremos, sino que, parece ser, la figura de la indeterminación, potenciada por los cambios de tiempo verbal, narrador e inclusión de las historias no verificables en la

\footnotetext{
3 "Entre", línea de fuga que pasa entre dos términos o dos conjuntos, estrecho arroyo que no pertenece ni a uno ni a otro, sino que los arrastra a los dos en una evolución no paralela (Deleuze y Parnet, 1980).

${ }^{4}$ Análisis realizado, en "Santa María en la literatura: Desde los versos populares hasta Rivera Letelier”, por Ostria, Aguayo y Alveal (2009).
} 
historia que entendemos real la que predomina como también la verdad novelesca que se nutre de la imaginación y lo cotidiano del existir que, más que mentira o ficcionalización, es posibilidad y encuentro... como dicen ahora: "rescate".

La perspectiva impersonal, el relato histórico, representarían lo disciplinario y la lógica objetiva; las otras voces, la historia de Olegario, el Jote, la de Idilio y Liria María, también con su carga onomástica, entregarían la imaginación refutadora y anticipadora, alejándose de la lógica convencional que se conecta de manera directa con las estructuras sintácticas que ordenan la recepción en un final anticipado y único.

El narrador objetivo, el que hace la crónica, separa el texto de su propio y natural devenir no lineal; cuando son otras las voces y Santana deviene otro, la narración queda supeditada al devenir del texto, relativizándose la lógica externa del discurrir narrativo omnisciente.

En términos del desarrollo secuencial, la novela, luego de avanzar por un territorio lírico y simbólico, se interna en el relato cronístico, hacia un territorio poco novelesco que resulta ser un no territorio. Finalmente, el relato termina entregándose a su destino novelesco, ya con una torcedura y doblez irreparable en su apariencia de sólo crónica o ficción.

Los movimientos del texto ya no son desde afuera hacia adentro y los movimientos verticales han sido sustituidos por los horizontales, pues, como escribe Deleuze, en ella es importante deslizarse a lo largo, de manera que la vieja profundidad ya no sea nada, reducida al sentido inverso de la superficie. A fuerza de deslizarse se pasará al otro lado, puesto que el otro lado es simplemente el sentido inverso. Y si no hay nada que ver detrás de la cortina, entonces es que todo lo visible, o más bien toda la ciencia posible está a lo largo de la cortina... (1971: 20).

La trampa de Rivera se efectúa a través de movimientos laterales, el movimiento del devenir, a lo ancho de lo visible. No puede verse de otra manera el devenir de Santana, su deslizamiento por la piel del texto que le hace experimentar ese proceso de inversión o de reversibilidad. Entonces, lo primero que se diluye es el valor del texto como pura referencialidad e historia o pura poesía o narrativa poética.

Se interroga la verdad histórica para establecer otras posibilidades, dejando transcurrir y ocurrir el flujo natural de una historia que no sólo es huelga, fracaso, muerte. La novela parece pasar-transcurrir entonces de la hipérbole de la muerte, del mal, de la peste, de los panópticos malignos, a la posibilidad de vida para, necesariamente, entrar en el riesgo de los recintos 
abiertos. La llamada historia oficial, la crónica, la sumisión a los relatos de lo visto y lo vivido por los "héroes" mayores constituyen el recinto cerrado e inmodificable; frente a ellos, la novela Santa María de las flores negras, como sitio de desestabilización, abre el relato para, incluso, dejarlo en manos del receptor y en el diálogo desestabilizador que, al menos, introduce la incertidumbre como única posibilidad.

El relato cerrado concluye con la muerte de más de tres mil seres humanos en la escuela Santa María de Iquique y la "normalización" de ese conflicto. El relato de los muertos que perviven en la memoria, el deseo de narrar otra dimensión y las pequeñas huellas, representados aquí por la voz de Olegario Santana, su corte de jotes y ánimas en pena, retornan en el espacio novelesco. En este espacio la historia del personaje arquetipo no concluye con la vuelta a la pampa, sino con un relato que trae a presencia lo que, a la manera de Juan Preciado y Dorotea, anima nuestra historia. Está también el germen de una historia posible que es la de Liria María e Idilio, a quienes dejamos frente al mar y cuya huella, podemos suponer, se pierde hacia el sur, allí donde es posible la esperanza. Planteamos, entonces, que la novela de Rivera Letelier es una novela histórica que vuelve a relatar hechos ocurridos y lírica que postula una utopía de cuya realización no hay noticias, pero que es, simplemente es. Así, en la novela, Liria María e Idilio no mueren ni retroceden al lugar de la infamante explotación, tienen los medios y sueñan el doble sueño de Talca y del amor que abre el relato a otros mundos posibles. En este sentido y también en otros aspectos la obra puede ser relacionada y presenta marcas de la retórica del folletín, podría plantearse esta lectura.

La novela trata, entonces, del poder: aspecto ideológico y político; de la muerte -Olegario y la muerte-: aspecto metafísico y de la vida: los relatos posibles. Está, además, la figura de la madre, que en la escritura de Rivera Letelier establece una relación (bodas escandalosas) con la prostituta como sagrada. Las interrelaciones de los aspectos utópicos, políticos y metafísicos constituyen el tejido de la novela, el movimiento mismo del proceso de su escritura.

\section{NOVELA E HISTORIA}

La obra de Rivera Letelier, que se puede incluir en la serie "Nueva novela histórica hispanoamericana", pues se nutre y crece paralela, en un diálogo
Seix Barral Biblioteca Breve

Hernán Rivera Letelier Santa María de las flores negras

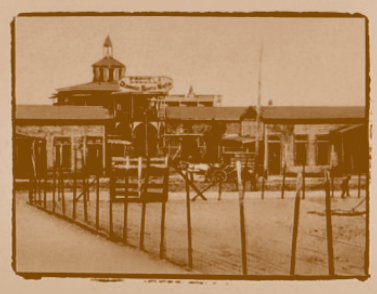


los obreros que en una cantidad de cinco mil ocupaban la escuela, la carpa del circo Zobarán y la Plaza Montt en esos segundos previos y antes del viaje? (VV.AA., 1998: 9).

De eso nos habla y a ello responde, con imaginación posibilitadora, la verdad novelesca de Santa María de las flores negras que, al dar vida y voz a las otras historias a través de las cuales se va componiendo un tejido, permite imaginar y comprender por qué lo ocurrido es fracaso y triunfo a un mismo tiempo y por qué todo(s) está(n) aún tan vivo(s). Santa María de las flores negras diseña, así, un espacio dominado por la muerte, pero seducido por la vida, trabaja con el principio de la movilidad, que replantea uno de los problemas de la novela contemporánea y su idea de una realidad en esencia inaprensible con los códigos convencionales del relato.

\section{PANÓPTICO, DESEO Y TRAICIÓN EN SANTA MARÍA DE LAS FLORES NEGRAS}

En su artículo "Novela y poder. El panóptico. La ciudad apestada. El lugar de la confesión" (2004: 47), Mario Rodríguez observa cómo la novela realista, específicamente la de aprendizaje, equivale en el plano ficticio a un dispositivo disciplinario semejante al panóptico descrito por Bentham (1979). Si arquitectónicamente el panóptico da cuenta de la estructura del narrador, "cartográficamente" ella -la novela realista- se acerca a la forma a la que habría que añadir (médicamente) el calificativo de ciudad enferma. El poder retícula a la ciudad-novela como si estuviera apestada, toda ella atravesada por la jerarquía, la diferencia, la vigilancia, la escritura ${ }^{6}$.

La relación con la peste, la ficción del carnaval, la fiesta perturban al narrador panóptico, quien se siente atraído por ese deseo transgresor y, discursivamente, deviene un "animal de confesión". En consecuencia, la novela ha sido una instancia más del orden disciplinario, aquel en que los

${ }^{6}$ Jeremías Bentham desarrolla la noción de panóptico como rasgo de la arquitectura carcelaria, como un lugar desde el que todo se pueda vigilar. Michel Foucault lo comprende como modelo de relación de la vida cotidiana de los hombres y mujeres del siglo XX, pues, más que una construcción arquitectónica ingeniosa, representa un tipo de sociedad que hace su aparición alrededor del siglo XVIII: "La antigüedad había sido una sociedad del espectáculo, así ocurría en los circos, los templos, los foros...”. La sociedad moderna, que ve nacer el panóptico, apunta al proceso inverso: desea "procurar a un pequeño número, o incluso a uno solo, la visión instantánea de la gran multitud" (Foucault, 1998: 218). Nosotros pensamos el panóptico como un artefacto aplicable, metafóricamente, a la novela y al narrador. 
sujetos deben ser vigilados, castigados y corregidos. En ella los roles están claramente definidos: el gran vigilante es el narrador, ente omnisciente que se oculta en las sombras y dispone de una visión panorámica de lo que está iluminado por el foco lumínico de la omnisciencia que sólo él posee y con el que ejerce un poder regulador, esquemático e inamovible. Esta concepción del orden literario es rota por la novela posvanguardista que se erige como el "espacio de la desintegración en el ámbito de la ficción literaria del orden panóptico". Para entenderlo hay que huir de las "buenas lecturas" y es necesario encontrarse con la multiplicidad de voces, límites y resistencias ofrecidas por las "malas lecturas", aquellas que no respetan los sentidos convencionales. Escapar de las trampas del panoptismo y realizar otras aproximaciones nos permite observar la incompatibilidad entre el antiguo orden narrativo y los nuevos esquemas novelescos, que realizan una progresiva subversión de los mecanismos disciplinarios, confesionales y cerrados.

Lo anterior resulta evidente en la novela de Rivera Letelier, en la que se reescribe, amplifica y da espesor al relato de lo ocurrido en Iquique. Santa María de las flores negras forma parte y completa un ciclo novelesco que crea el imaginario del salitre "y que, aquí, reconstruye, con notable maestría, uno de los hechos más traumáticos de la historia chilena".

En una primera aproximación, la novela muestra una exacerbación de la muerte: la sangre, los cadáveres llenan el espacio: hay jotes, suicidas, zonas desiertas y ominosas, matanzas. La violencia inunda el texto y la dama negra está en todos lados y nada parece escapársele. El relato resulta casi la escenificación de un ritual mortuorio en el cual los protagonistas, que recorren un tortuoso camino para reclamar sus derechos, acuden a sus propias exequias, después de velar y ser velados en una escuela que debió, como su nombre lo dice, ser protectora y maternal. Sin embargo, entre las abundantes reclamaciones y figuraciones de la muerte que se incluyen, quizá la más intensiva sea la personificación de ella en Olegario Santana, "El Jote". Este personaje y narrador protagónico de especiales características, fronterizo y anomal, es la imagen viva de la muerte y su corte de jotes el augurio constante de la misma: "Sobre el techo de la casa, recortados contra la luz del amanecer, los jotes semejan un par de viejitos acurrucados, vestidos de frac y con las manos en los bolsillos". Los jotes, en contigüidad con su "amo", estáticos como figuras de veletas, y nimbados por un vaho de podredumbre parecen dormir hondamente uno junto al otro (...) "Olegario Santana tenía ropa negra y nariz ganchuda, por eso le llamaban 'El Jote”" (Rivera Letelier, 2005: 9-13). No obstante, otros signos van evidenciando que la novela 
no es sólo un instrumento del proyecto disciplinario, ni un relato de pura muerte, sino asimismo un espacio de subversión de ese mismo intento y en el cual también resplandece la vida.

Estamos hablando de la aparición de un relato fantástico/utópico o poético que libera estéticamente aquello que es reprimido por la zona realista o historia tradicional. Hablamos de la creación de "ciudades ausentes" en las que, sin reprimir lo múltiple, se escribe por el "pueblo que falta"; se consigue la invención de un héroe traidor, de la contraciudad y se exhibe la presencia del amor en tiempos de ira. Centrándonos en el nivel narrativo, observamos que cuando se inicia el discurso, quien narra conoce cada uno de los aspectos del universo literario en el cual participa, se trata de un ente que anticipa el destino del relato y los sucesos, situándose en un lugar privilegiado para "vigilar" y relatar, tanto desde arriba como desde el interior de las acciones. Es un pequeño dios que todo lo sabe; pero, casi, al mismo tiempo, se incluye un plural afectivo cuando utiliza el "nosotros" para referirse a los huelguistas. El narrador omnisciente-actor vigilante no se muestra, permanece en la oscuridad, pero proyecta luz hacia cada espacio al que dirige su mirada: atraviesa los cuerpos hasta llegar a lo más íntimo de los individuos que observa para reconocer, anticipar y visar sus deseos y actos; parece, asimismo, mártir de su propio saber, según el cual todo será muerte y sepultura. Sin embargo, al cumplirse el desenlace de los acontecimientos, ese que había custodiado, con la distancia del saber, se muestra como uno más de los sacrificados y sabemos que habla desde un lugar imposible, ya abierto por Juan Rulfo, desde la tumba. Ha estado en la sombra; pero clamando por reivindicación y quiere que su voz salga a la luz como uno de los protagonistas de los hechos, traicionando su rol, su equidistancia y su voyeurismo para subvertir el orden panóptico del cual es el centro. Ha ocurrido la empatía, el amor, la "conversión" y la compasión de la que también Rivera Letelier tiene ejemplos en su tradición literaria.

El narrador, devenido traidor de su orden, ha dado pistas de su ubicación, ha dejado entrever que su espacio es el de la muerte y desde ella empieza su relato. El primer fragmento de la novela muestra la soledad de la pampa y del hombre acompañado por un par de jotes que ha criado y alimentado. Esta rara figura de la muerte parece ser quien dirige la mirada del narrador, puesto que el "vigilante" sólo muestra aquello que es enfocado por la mirada del "Jote", que lo fascina y a quien sigue, apartándose sólo en aquellos momentos en que irrumpe la vida para finalmente situarse en el mismo espacio de la muerte. Es en este lugar en donde de verdad parece ocurrir la narración cuyo origen se ha enmascarado: el narrador está 
muerto y es la muerte misma la que lo guía y le ha permitido todo saber... incluso el que habla por la vida. No es simple coincidencia que, de manera similar al del narrador panóptico, el Jote siempre estuviese bajo la sombra de su negro sombrero y oculto en la oscuridad de su paletó negro del que, por una parte, saca el dinero, que permite la huida de la ciudad apestada, panóptica y mortífera y, por otra, ocurre la fuga narrativa:

- Esto es para que se embarquen hacia el sur -les dice.

Los jóvenes lo miran incrédulos.

-Son los ahorros de todos mis años en la pampa. Creo que con esto les alcanza también para comprarse una parcelita.

Al ver las lágrimas en los ojos de los jóvenes y sentir la propia emoción atragantándolo por dentro, el calichero se refugia en una de sus escasas salidas de humor.

-Ahora ya saben por qué no me quitaba el palo ni para dormir-dice mostrando sus dientes nicotinosos.

-Pero ese dinero significa el esfuerzo de toda su vida -le reprocha sollozando Liria María.

-Ustedes lo necesitan más que yo -dice Olegario Santana-. En realidad no sé para qué diantres estaba ahorrando tanto, si ya me quedan pocas vueltas en la carretilla. Además, como diría seguramente la abuela sabionda del jovencito aquí presente, "La mortaja no lleva bolsillos" (Rivera Letelier, 2005: 251).

El narrador vigilante que circula en la novela no es la única figura del poder que intenta silenciar lo que para el orden del poder es indecible. Esta función también se evidencia en las instituciones que al interior del relato se encarga de mantener y resguardar el esquema social disciplinario: el Estado de Chile, el ejército, los patrones y empresarios, los dirigentes gremiales, los periódicos. Ellos instauran y sostienen el orden que gravita sobre los cuerpos y almas del proletariado. "Los vigilados" se ven traicionados por aquellos que creían sus protectores. El Estado y el ejército se han tornado traidores en la conciencia de la gente; sin embargo, la traición cometida en contra de su propio pueblo representa, según la ideología propia, sólo una parte más de sus funciones, es su obligación. Con la matanza se busca (castigar) eliminar el germen de la rebelión y de la expansión de la peste. Al abrir fuego en contra de los suyos, los soldados simplemente están (disciplinando) castigando a aquellos cuyos cuerpos han dejado de ser "dóciles" y que de observados han devenido observadores y transgresores de la zona de sombra.

Es entonces cuando la figura del "traidor", a través de múltiples facetas, 
se erige como un tópico fundamental de esta novela, en protagonista del juego de traiciones que se evidencia al interior de la obra y que "contagia" cada estrato de la narración, alcanzando su máxima expresión en la imagen del "traidor" devenido héroe novelesco. Ese ser que, desoyendo su propia naturaleza, rechaza el cumplimiento de su misión, alterando y destruyendo el normal funcionamiento de los mecanismos disciplinarios que componen el texto en su nivel narrativo.

Otra muestra de la fractura del papel tradicional del narrador se evidencia en la progresiva fascinación que producen en él aquellos que deben ser vigilados. Así se hace cómplice de sus actividades, pronto no sólo las observa, sino que parece compartirlas y disfrutar con ellas. De pronosticar sólo desastre y muerte, de formular advertencias, pasa a liberarlos; deja que Olegario se inunde de amor y vida y, poco a poco, su mirada no esquiva las ventanas utópicas, sino que colabora para que se mantengan por más tiempo abiertas, dedicándoles un espacio cada vez mayor en su narración. El "Jote" se deja seducir por la esperanza y su presencia en esta zona es cada vez más notoria. Del mismo modo, la mirada del narrador se va extraviando, la causa del traidor lo fascina y consigue apartarlo de su rol de vigilante omnisciente. Sus imágenes ahora se entrecortan y debe hacer grandes esfuerzos por volver a su objetivo (los vigilados). Es que Olegario gobierna su visión y la traición del Jote se ha vuelto también la suya. El narrador reniega (al igual que su héroe) de la muerte y, entonces, la única instancia de castigo posible se ve así traicionada y el ordenamiento panóptico, superado. Esta transgresión también queda expuesta en el esfuerzo del narrador por preservar la naturaleza del lenguaje típico del obrero salitrero, la jerga del pueblo, transformándose en una instancia de fuga pues contiene la identidad del proletariado y representa un espacio libre en el que la mirada inquisidora del amo aún no ha penetrado. El cronista no reprime la mezcla de voces, más bien la alienta, confundiendo su lenguaje con el de los vigilados, con el habla de la pampa, de la bohemia popular, de los extranjeros, de lo reprimido que busca la liberación

El relato deja abiertas diversas "zonas de fuga", que se acrecientan a medida que se avanza en la narración. El lenguaje del pueblo, cada más representado, es apenas un ejemplo de ello; los deseos y saberes vigilados se abren paso aprovechando los continuos, y cada vez mayores, extravíos del narrador. Otro ejemplo de esta liberación es el lugar predominante que ocupan los "espacios de placer" en esta novela, en la que el prostíbulo ayuda a desatar los saberes ocultos y en la que se explícita que el placer sexual engendra vida, y saber. El narrador se sirve del espacio del prostíbulo para 
hablar de eso otro que la sociedad disciplinaria prohíbe abiertamente: el sexo. Mediante el estudio y la exposición del erotismo de los cuerpos (no) disciplinados se pretende buscar la verdad. Por otra parte, el hecho de que "lo indecible" sea liberado por el relato novelesco es resultado de la aplicación del propio orden panóptico, dado que éste trabaja con los detalles más íntimos de la vida cotidiana de los individuos vigilados, provocando así una paradoja, en el sentido de que la obra se vuelve al mismo tiempo un dispositivo de aplicación y una instancia de resistencia al poder disciplinario. En un nivel se explicita la intimidad de la vida de los obreros y sus familias, mediante la exposición del contenido de los libros de "registro" y en otro se propicia la liberación estética de lo reprimido, dando cabida a aquello que no debe mostrarse. En su afán por exponer los detalles registrados, el narrador se ve envuelto en las trampas de la exposición panóptica que lo lleva a observar y exponer aspectos prohibidos por su propio esquema: Por ejemplo, la ficción de la fiesta y el carnaval, al representar explosiones de vida, resisten a la muerte y la bohemia de los bares, el circo, los prostíbulos, representan espacios de liberación para el pueblo para el que sólo existen el orden del trabajo y la obediencia.

Se hace presente además un espacio que no existe, un lugar que no está: la "ciudad ausente", el lugar de la utopía, territorio creado por y para los trabajadores de la pampa. Ellos, los vigilados, constituyen un pueblo lleno de ausencias, compuesto por exiliados y raptados, inmigrantes, gente de ilusiones rotas que busca el abrigo de una quimera que estaría en el anhelado sur, la verde tierra de sus sueños. En el universo ficticio del cine y sus paisajes idílicos existe el verde valle donde la felicidad es posible. Es el país multiétnico, es el sueño en el que bolivianos, peruanos y chilenos viven ajenos al rencor de la reciente guerra fratricida que envolvió a sus nacionales donde sus voces se mezclan, originando un relato multiforme, ajeno a toda represión.

También, desde otra perspectiva, esta novela puede considerarse como un muestrario vivo del funcionamiento del poder disciplinario al exponer cartográficamente que, tanto en la "ciudad apestada" como en los campamentos salitreros de la pampa, rigen las reglas explicadas por Foucault para vigilar y castigar. Estos poblados, fundados por las empresas como aldeas mineras, se organizan en torno al (libro de) registro, el archivo y la anotación; los 'apestados' pueden ocupar sólo el espacio designado y sus vidas eran custodiadas mediante el más estricto sistema de vigilancia. De la misma forma, las autoridades políticas quieren que se aprecie a la ciudad de Iquique, contagiada por la masa de trabajadores enfermos, venidos desde 
el interior del desierto. Los huelguistas son tratados como entes repulsivos, infectos, con los que no se debe mantener contacto pues representan una amenaza letal para la población sana de la ciudad. El recinto de la escuela también se organiza mediante esta configuración. Se trata siempre de instituir forzosamente un orden donde cada individuo ocupa un lugar susceptible de ser vigilado, de controlar su "ruin" deseo de justicia. El efecto de este dispositivo de control es el amontonamiento de los cuerpos infectados con el fin de evitar, a toda costa, el contagio de la peste maléfica a la población sana.

El traidor, como ya señalamos, es una figura esencial de esta novela y, fundamentalmente, se trata del sujeto que ha rechazado su propia condición disciplinaria para ceder espacios a otros. Olegario Santana, ser lúgubre, casi siniestro, representa para el universo del autor la personificación misma de la muerte, pues cada detalle lo asemeja al encapuchado cuyos dedos descarnados manejan la guadaña; es la parca, el Caronte, que acompaña a los caídos hasta su última morada y el encargado, en fin, de llevar a los huelguistas al lugar del sacrificio, para asegurar así el alimento de los jotes del averno. Sin embargo, finalmente es él quien se sacrifica, traicionando su rol, su deber de parca, para instalarse al lado de la vida. Esta traición es motivada, entre otras cosas, por el influjo del amor por Gregoria Becerra. Este sentimiento provocado por la mujer y nuevo para su frío corazón, lo lleva a atentar contra su propia identidad. Así resulta que sin su sacrificio, su traición y su devenir no podrían llegar a romperse las murallas del orden panóptico imperante que considera la muerte como la instancia suprema de la disciplina. La traición del Jote viene a demostrar que en la muerte también es posible encontrar la victoria y que la oscuridad de la tumba es un abrigo seguro a la mirada del gran vigilante. Desde allí las voces no pueden ser acalladas. Olegario Santana debe, por lo tanto, traicionarse a sí mismo, sacrificarse ante la vida, para ceder su lugar al narrador devenido traidor, quien se ha hecho cómplice de la vida para lograr sus objetivos.

Gestualmente, el "Jote Olegario" demuestra que se ha entregado al otro bando al ceder su sombrero para cubrir y proteger al líder de la huelga que ha quedado descubierto ante la luz y el peligro. Después, se quita su "paletó negro" y, como hemos recordado, entrega todo el dinero que en él escondía a la joven pareja que representa la esperanza y que acaba de conocer el amor en medio del sufrimiento y la pérdida.

El sacrificio de Olegario, "El Jote", representa el tópico de la muerte fecunda del héroe, pero de manera invertida. De un lado están los trabajadores que sucumben para reivindicar y salvar al proletariado universal; 
del otro, Olegario, cuya muerte simbólica es irse hacia el lugar de la vida. El sabe que para ganar la lucha es necesario morir, pero su sacrificio consiste en elegir la vida, hecho paradójico y profundamente simbólico y que lo lleva a devenir anti-héroe o héroe-traidor en todos los sentidos. Nunca será considerado mártir, máxima figura heroica en nuestra cultura, sino un traidor, un ausente. Este es el regalo que entrega a los inmolados de Santa María. Esa es su traición, su sacrificio por la reivindicación del pueblo oprimido.

Los personajes de la novela parecen estar en todo momento presos del panoptismo: el desierto, las distintas oficinas salitreras, la ciudad de Iquique y, finalmente, la escuela articulan desde afuera hacia adentro la serie de anillos superpuestos que constituyen una arquitectura disciplinaria. Frente a este ominoso dispositivo de vigilancia y castigo existen contrafiguras tales como "la ciudad ausente", el mundo ficticio y anhelado del cine mexicano, la bohemia de las ciudades fantasmas del norte desértico, quizás la propia oficina salitrera con sus arrebatos carnavalescos, en algún momento incluso lo ha sido Iquique, mediante sus lugares de placer (el circo, los prostíbulos). Estos espacios son verdaderas zonas de resistencia, espacios de libre flujo del "deseo" de rebelión y reivindicación en los que proliferan lo que Gilberto Triviños (2006), lector de Baudrillard, llama testimonios de la indestructibilidad del deseo. El deseo perturbador de justicia o libertad es, por una parte, lo que siempre está reprimido, pero, por otra, lo que es indestructible y puede ser actualizado siempre.

Existe otro aspecto de la novela en el que se puede ver con nitidez cómo van quedando abiertas ciertas ventanas utópicas a través de las cuales la muerte no es vista como una figura nefasta. Así, por ejemplo, el cariño que nace entre Gregoria Becerra y Olegario Santana revela que hasta en la muerte existe amor y que, aun después de muertos, los amantes continúan entregándolo: utopía o cursilería folletinesca, según se lo quiera, y la muerte es el sacrificio extremo que se realiza por amor. Gregoria Becerra: "Siente con Olegario Santana lo que sentía cuando su marido estaba vivo". Por otro lado, en la escena en que Idilio Montaño y Liria María -quienes en medio del conflicto inician un romance- consuman su sentimiento amoroso, el narrador dice: "Ella llora de amor. Él parece morir de felicidad" (Rivera Letelier, 2005: 228). Nuevamente vida, muerte y amor no son instancias opuestas en la novela de Rivera Letelier: unas y otras constituyen la misma fuerza generadora de triunfo, el espacio de los anhelos, la esperanza de una vida justa. Los huelguistas que aguardan la muerte "con el ánimo exaltado 
y dispuestos al sacrificio más extremo" (Rivera Letelier, 2005: 209) declaran por ello que están dispuestos a morir en la lucha si es necesario.

El sacrificio de la niña Pastoriza del Carmen, narrado desde las palabras de Idilio Montaño, es relevante en este sentido:

murió la niña pastoriza [...] ella fue una de las personas que murieron aquí... simplemente dejó de respirar y se murió [...] yo creo que no quiso vivir nomás [...] hoy en la mañana la acabamos de sepultar, envuelta en su capita de virgen y con su corona de cartón dorado (Rivera Letelier, 2005: 250).

Esta muerte representa el sacrificio de la inocente. La pequeña criatura no sólo acepta morir, sino que ella misma se ofrece en sacrificio, sin necesitar de expiación. Pero su voz no será escuchada, sus reclamos no existen, porque Cristo no murió para conseguir reivindicación, él se elevó de entre los muertos, afirmando que en medio de la muerte existe la vida. La muerte de los obreros masacrados por su clamor de justicia, los hace indestructibles. Sus voces ya no son ecos remotos, inaudibles, sino gritos de esperanza convertidos en memoria imborrable de un pueblo que sólo parece muerto.

[...] sabemos que nuestra muerte no será del todo inútil [...] el mundo entero sabrá que esta matanza perpetrada un 21 de diciembre de 1907, en los recintos de la escuela Santa María de la ciudad de Iquique, fue la más infame atrocidad que recuerde la historia del proletariado universal (Rivera Letelier, 2005: 254).

La misteriosa figura de "el buitre", sobrenombre tomado del ave que siempre ha estado cargada de un aura siniestra, al tratarse de criaturas devoradoras de cadáveres, evoca una muerte grotesca, sórdida y representa fatalidad; sin embargo, se sabe que estas aves no siempre son consideradas mensajeras de mortandad. En los albores de la humanidad civilizaciones tan influyentes como la egipcia veneraban a los buitres, considerándolos símbolos de fertilidad; en el antiguo Egipto son identificados con la diosa Mut, madre del dios Joshu, a la vez que del rey (Faraón) y de la tierra, la esposa de Amón. Asimismo, durante el período de la reunificación, se le identificó con la diosa Nejbet, patrona del Alto Egipto (la de la corona blanca, deidad de la vida y la fertilidad).

La identificación del buitre o Jote con la naturaleza femenina y los principios generadores de vida parecen no escapar al entendimiento del au- 
tor quien, en obras anteriores, evoca la presencia de la "Diosa Madre" y su representante en la Tierra, "la Prostituta Sagrada". Son las meretrices del desierto, cuya función es brindar el "ánima” (vida) al mundo. Se elimina así la noción de "prostituta profana", elevando a la categoría de divinidad sostenedora y primordial a cada una de las meretrices. La prostituta sagrada, encarnada ejemplarmente por Yolanda, representa el "pueblo que ríe" que resiste en Santa María de las flores negras. Ella es la que otorga vida a un espacio infernalmente muerto. Es María Magdalena, la diosa madre, la diosa que ríe, el espíritu del pueblo, la encarnación de la diosa creadora.

La reivindicación del erotismo femenino, que limpia la sexualidad de su aura negativa y sucia (la prostituta profana), tiene así una importancia fundamental en la lectura de la novela de Rivera Letelier como texto que emancipa del dispositivo panóptico y represor implacable de la "ruin imaginación" del deseo de justicia de los vigilados, de su exigencia de vida en un espacio de superabundancia de muerte.

Existe además un rasgo que potencia el aspecto sagrado que adquiere la prostitución en esta obra. Nos referimos al tópico de la "hierogamia". La unión sagrada entre seres divinos, en el caso de Santa María de las flores negras, es la relación, más espiritual que corporal, entre Olegario Santana, personificación de la Muerte, y Yolanda, la Prostituta Sagrada.

En relación a la imagen femenina de la divinidad elaborada novelescamente, cabe mencionar que Yolanda es el ingrediente esencial para el triunfo de la reivindicación. Ella es, junto a Gregoria, la figura de la madre, esa que lleva a Olegario a traicionar su rol. Yolanda y Gregoria son entonces la misma diosa creadora, figuras de la fertilidad, que hacen posible la vida aun en medio de la muerte. Su misión es mantener vivo el espíritu del pueblo, a través de su erotismo y sensualidad, de sus consejos y cuidados. "Flores negras para / la vida y el ánima" (Qualls-Corbet, 1990: 25).

Es preciso mencionar, asimismo, que el elemento sublime como el grotesco conviven de manera armónica en esta dimensión planteada por la novela. De un lado están los mineros, verdaderos nibelungos que acrecientan y custodian el tesoro de los patrones, viviendo en situaciones infrahumanas, habitando en lugares menos aptos para la vida. El campamento minero y luego la escuela Santa María en su totalidad forman parte de esta realidad distorsionada por el elemento grotesco que todo lo impregna: casas, ropas, calles, rostros, e incluso el aire, que no pueda ser respirado. Pero, por su parte, está lo "sublime". Es el elemento divino que acompaña al pueblo, que aparece en la imagen de las casas de los patrones, a las cuales "ni el polvo se atreve a tocar", pero que también se hace palpable en las noches eternas, en 
las parrandas épicas en las que el proletariado moribundo busca aferrarse a la vida: Escuela y Santa María.

Santa María de las flores negras es, entonces, una novela histórica que recrea una historia de superabundancia de muerte, pero que, a la vez, devuelve el "ánima" a los muertos aún sin sepulturas de la matanza de Santa María.

Rivera Letelier, a través de su arte, de su literatura, abre su narrativa a lo borrado por la historiografía oficial chilena: las voces de las víctimas, el sueño de los inmolados y su esperanza indestructible.

Así leída, la novela se inscribe, finalmente, en una doble tradición literaria: la del imaginario de la pampa salitrera, que recrea y reivindica, desmantelando para ello la estructura panóptica, fundado en el miedo a los deseos perturbadores, de la literatura realista y la serie literaria canónica de la literatura latinoamericana.

\section{BREVE APUNTE DE INTERTEXTUALIDAD}

Quisiéramos anotar brevemente que Santa María de las flores negras realiza un diálogo fecundo con Pedro Páramo de Juan Rulfo (1967 [1955]) y con Canto general de Pablo Neruda (2009 [1950]). Su interés en este aspecto es doble: se conecta creadoramente con la nueva narrativa histórica hispanoamericana y, a la vez, con la gran literatura de la muerte en América hispánica.

La novela comparte con Pedro Páramo una gran cantidad de rasgos. Rivera Letelier intenta imitar la creación de Rulfo, escuchando las voces de Comala e intentando dialogar con ellas a través de sus personajes. Tanto es así que a nadie llamaría la atención si el narrador de la novela de Rivera Letelier fuera Juan Preciado. Cada página de uno y otro texto se encuentra impregnada por la obsesión de la muerte. Las historias narradas forman un caos, se presentan cortadas y en ocasiones hasta carentes de sentido, porque emanan de una multiplicidad de voces diferentes, de seres para los cuales el tiempo ha dejado de ser lineal, porque hablan desde la penumbra, desde la muerte. Los murmullos de los muertos cuentan la historia en la novela de Rulfo; y lo mismo pasa en la de Rivera Letelier.

Resbalando en los charcos de sangre humeante, pasando por encima de nuestros compañeros muertos [...] Y de los que se hacían los muertos, cobijándose debajo de los cadáveres, para, de ese horrendo modo, salvar sus vidas [...] Éramos repelidos sin piedad por los soldados de la masacre (Rivera Letelier, 2005: 253).

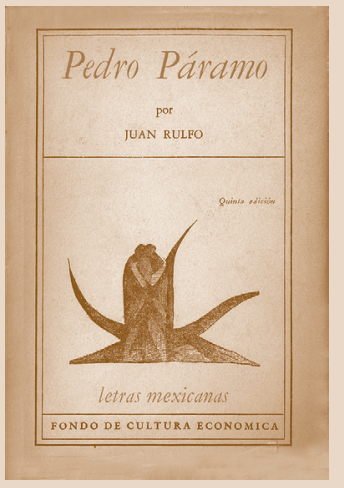




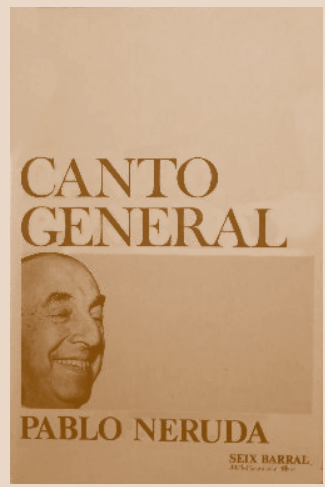

El universo de Rivera Letelier es la pampa y el desierto salitrero, lugares que en muchas ocasiones llama "páramos infernales", Comala también se ha transformado, por obra de Pedro Páramo, en un sitio intermedio entre el Cielo y el Infierno. Es un lugar muerto, tal como Olegario Santana ve a Iquique, después de la masacre. La ciudad ya no es la misma, se dice incluso que nada puede erradicar de ella el olor de la sangre de los muertos.

Es importante mencionar, asimismo, que en las dos novelas el poder de la autoridad se ejerce a través de una vigilancia extrema. La imagen de un panóptico que todo lo conoce y domina se encarna en la figura de los patrones: Pedro Páramo es omnipotente en su pueblo y los administradores de la mina lo son en las salitreras.

Santa María de las flores negras es también capaz de dialogar con Canto general de Neruda. Nos referimos a que el mito estructurante de uno y otro texto es el mismo. El mito del pueblo indestructible y, dentro de ello, la visión del poeta y del novelista como los que escuchan las voces de los muertos. Neruda dice: "yo te oigo, hermano muerto, hermano, hermano vivo, te oigo,/ Lo que tú deseabas, lo que enterraste, todo,/ la sangre que en la arena y en el mar derramabas,/ El corazón golpeado que resiste y asusta" (Neruda, 2009: 269). Rivera Letelier, muchos años después, testimonia la misma "norma del mundo"; el pueblo, en un aspecto, está siempre muerto; en otro, es indestructible. "La sangre de las primeras decenas de muertos cercenados por la metralla formaron rojos charcos humeantes que se sumían oscuramente en la tierra e impregnaban el aire de un denso olor ardiente" (Rivera Letelier 2005: 2).

Santa María de las flores negras habla de flores negras que, como las mariposas, revelan el ánima de los muertos; están en un lugar sagrado de la memoria escrita porque, como dice Octavio Paz (1969), estos muertos perviven porque "Si el hombre es polvo / Esos que andan por el llano son hombres, mujeres, niños”.

\section{REFERENCIAS}

Aínsa, F. (1986). Identidad cultural de Iberoamérica en su narrativa. Madrid: Gredos.

Bentham, J. (1979). El panóptico. Madrid: Las Ediciones de la Piqueta.

Chevalier, J. (1991). Diccionario de los símbolos. Barcelona: Herder.

Deleuze, G. (1971). Conversaciones. Valencia: Pre-Textos.

Deleuze, G. y Parnet, C. (1980). Diálogos. Valencia: Pre-Textos.

Foucault, M. (1998). Vigilar y castigar. México: Siglo XXI. 
González Miranda, S.; Illanes, M. A. y Moulian, L. (1998). Poemario popular de Tarapacá. 1899-1910. Santiago: Lom.

Neruda, P. (2009 [1950]). Canto general. Buenos Aires: Losada.

Ostria, M.; Aguayo, G. y Alveal, N. (2009). "Santa María en la literatura: Desde los versos populares hasta Rivera Letelier”. Revista Chilena de Literatura 75, 271-293.

Paz, O. (1969). “Aparición”, en Ladera este. México: Joaquín Mortiz.

Qualls-Corbett, N. (1990). A prostituta Sagrada, a Face Eterna do Femenino. Sao Paulo: Ediciones Paulinas.

Rivera Letelier, H. (2005). Santa María de las flores negras. Santiago: Planeta.

Rodríguez, M. (2004). "Novela y poder. El panóptico. La ciudad apestada. El lugar de la confesión”. Atenea 490, 11-32.

Rulfo, J. (1967) [1955]. Pedro Páramo. México: Fondo de Cultura Económica.

Triviños, G. (2006). "Mariluán de Alberto Blest Gana: Panóptico, utopía, alteridad”. En: Rodríguez, M. y Triviños, G. (eds.). Utopía y mentira de la novela panóptica (pp. 49-75). Concepción: Universidad de Concepción.

VV.AA. (1998). A 90 años de los sucesos de la Escuela Santa María de Iquique. Santiago: Lom. 